Acta Regionalia et Environmentalica 1

Nitra, Slovaca Universitas Agriculturae Nitriae, 2019, pp. 20-24

\title{
ENERGY PRODUCTION POTENTIAL OF WOOD BIOMASS FROM SRC PLANTATIONS IN CADASTRAL AREA OF NOVÉ ZÁMKY
}

\author{
Martin HAUPTVOGL*, Tomáš PESZEKI
}

Slovak University of Agriculture in Nitra, Slovak Republic

\begin{abstract}
The renewable energy sources play an important role in the discussions on the future energy generation. The European Union has set certain goals to increase the share of renewable energy sources and to reduce carbon emissions. The paper focuses on the evaluation of energy production from short rotation coppice (SRC) plantations in the cadastral area of Nové Zámky. The study area is located in south-western Slovakia. The energy production was evaluated based on GIS analysis of agricultural land suitable for establishment of short rotation coppice plantations. The high-quality arable land was excluded from the biomass production. The wood biomass should be produced on marginal, low-quality soils and contaminated or degraded land that is unsuitable for food production. There are only high and medium-quality soils classified in the qualitative groups 1-7 in the study area. The land potentially used for biomass production represents an area of 1,536 ha. If the whole area would be covered by short rotation coppice plantations, it would produce $4.8 \mathrm{kWh} /$ day per person. Taking into consideration the overall losses of $33 \%$ in the process of the energy conversion, the potential power from the wood biomass production is $3.2 \mathrm{kWh} /$ day per person. The plantations would provide 61 new jobs in the study area.
\end{abstract}

Keywords: renewable energy, short rotation coppice, soil quality, south-western Slovakia

Renewable energy sources (RES) are considered as a new model of energy for sustainable development (Dincer and Acar, 2017; Vidadili et al., 2017). In Europe, efforts are being made to completely replace fossil fuels and produce the overall energy from the RES based on the Smart Energy System concept (Connolly, Lund and Mathiesen, 2016). The term green economy is becoming increasingly common. It is defined as a system that leads to the improvement of human well-being and social equality while significantly reducing environmental risks and ecological shortcomings. In the green economy, revenue growth and employment are generated by public and private investments that reduce carbon emissions and pollution, increase energy efficiency and resource use and prevent loss of biodiversity and ecosystem services (Gasparatos et al., 2017). The European Union (EU) has set goals to increase the share of renewable energy sources and to reduce the amount of carbon emitted to the atmosphere by anthropogenic activities. However, climate change goals could be missed unless there is larger decarbonization of the energy sector (Khanam et al., 2017). Bioenergy is seen as a tool that could help to reduce the dependence on energy importing countries and promote sustainable development. There are certain constraints though that need to be considered including the amount of land required and carbon leakage in the process of biomass production (Bilgili et al., 2017). Biomass energy currently accounts for about $10 \%$ of global energy production. Twothirds are generated in less developed countries, with only $7 \%$ of biomass resources being used worldwide (da Costa et al., 2018; Welfle, 2017; Narayan, 2007). Wood biomass from plantations in the combination with wood from forest could play an important role as an energy alternative in Europe (Mola-Yudego et al., 2017). The aim of the paper is to assess the potential of local energy production from short rotation coppice plantation in the cadastral area of Nové Zámky.

\section{Material and methods}

\section{The study area}

The cadastral area of Nové Zámky is located in the southwestern part of Slovakia on the Danubian Lowland $\left(47^{\circ} 59^{\prime} 08^{\prime \prime} \mathrm{N} 18^{\circ} 09^{\prime} 28^{\prime \prime} \mathrm{E}\right)$ at an altitude of 119 masl (Figure 1). The land relief does not pose any obstacles to territorial development or transport and provides suitable conditions for economic and agricultural use of the territory. The town is an administrative centre of the Nové Zámky District. The population of Nové Zámky is 38,486.

The District is characterized by a warm and very dry climate with a mild winter. It is the warmest area in Slovakia (Lapin et al., 2002).

The arable land has a dominant position in the land use of the study area. The total area of the cadastre is $7,256.5$ ha and the agricultural land represents $5,388.4$ ha which is 74\% (Aurex, 2016). The soils are moderate loam with the dominance of chernozem. The humus content is high, more than 2.5\% (Marsina and Lexa, 2002). 


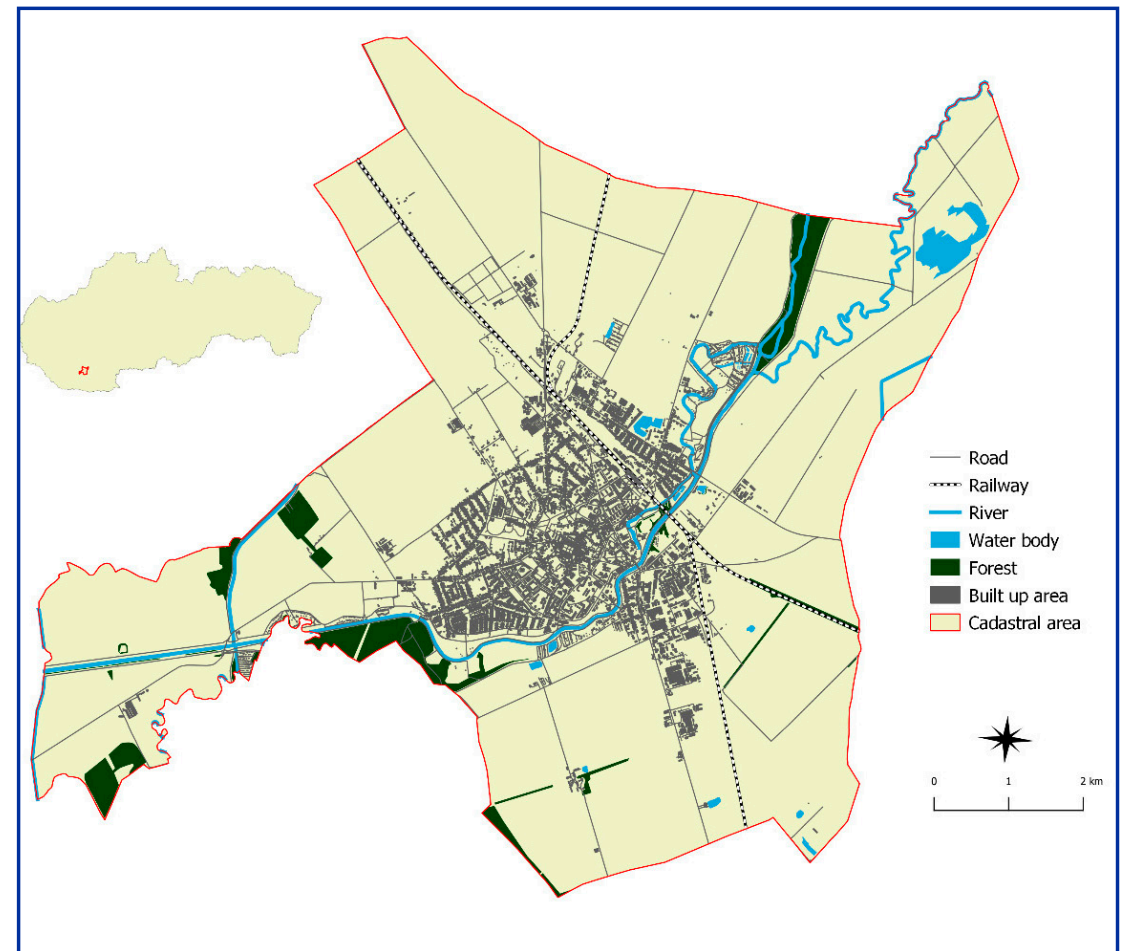

Figure 1 Cadastral area of Nové Zámky Source: author

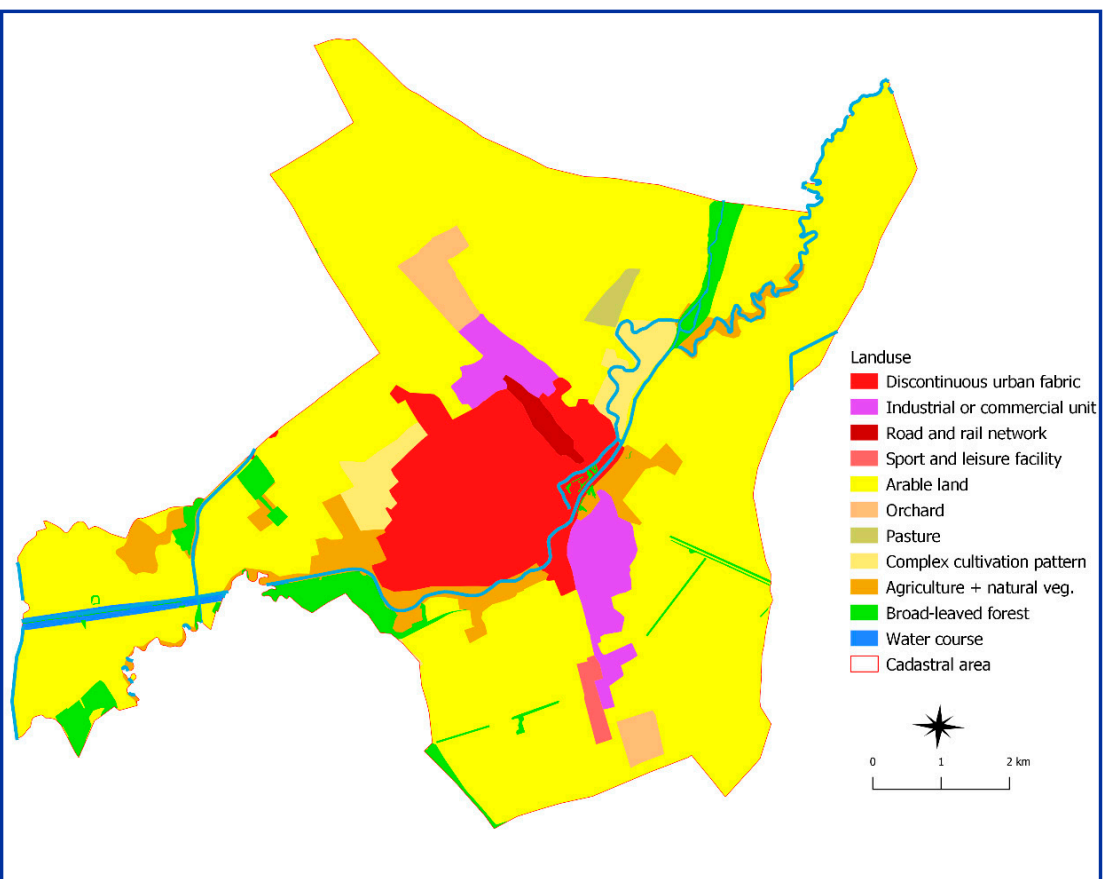

Figure 2 Current land use of the cadastral area of Nové Zámky Source: author
At present, there are two facilities utilizing renewable energy sources in the cadastral area: hydropower plant Zúgov and cogeneration unit for wood chips and natural gas combustion producing heat and electricity.

\section{Data collection and processing}

The available vector and raster data for the GIS analysis were obtained from the soil portal of the Soil Science and Conservation Research Institute (SSCRI), the European land cover mapping project Corine Land Cover 2012 (CLC) provided by EEA, Geofabrik $\mathrm{GmbH}$ Karlsruhe and National Geoportal of the Slovak Republic (Geodetic and Cartographic Institute Bratislava). The data obtained were processed in the open source GIS software QGIS (version 2.16.3). The vector data of evaluated soil-ecological units were analysed to determine the soil types and the soil qualitative groups. The lowest quality soils in the study area were located. These soils were evaluated as potentially suitable for the establishment of short rotation coppice plantations. The rest of the arable land consisting of the highquality soils should be used primarily for the food production. The amount of the energy produced from the plantations was calculated based on the total area of the plantations and the average dry above-ground biomass production of $12 \mathrm{t} / \mathrm{ha}$ (Tóth, Stričík and Kuffa, 2015). The potential number of jobs was calculated according to Varga and Bartko (2010).

\section{Results and discussion}

The arable land represents the biggest share of land use in the cadastral area of Nové Zámky. It is used mainly for food production and covers 5,017.5 ha. The forest area represents 295.2 ha. The areas of permanent grasslands and orchards are 29.7 ha and $121.6 \mathrm{ha}$, respectively (Figure 2 ).

There are five soil types in the study area. Chernozems and mollic fluvisols are the most dominant (Figure $3)$. The whole area is characterized by very fertile and high-quality soils and belongs to the most important agricultural region in Slovakia. The least fertile soils in the study area are 
regosols that represent only about $1 \%$ of the arable land.

According to the Act No. 220/2004 on the Protection and use of agricultural land, the soil-ecological units are divided into 9 qualitative groups. The groups 1-4 are highquality protected agricultural soils. The groups 5-7 are medium-quality soils and the groups 8-9 are low-quality soils. The groups 5-9 can be used for alternative purposes including biomass production. The study area is characterized by the prevalence of high-quality soils. There are no lowquality soils (Figure 4).

The soil erosion was analysed based on the System of evaluated soil-ecological units (Stred'anská and Budaj, 2006). The analysis showed that there is no potential threat of water erosion in the study area. Only 27 ha and 562 ha of agricultural land are potentially threatened by extreme and high wind erosion, respectively. It represents around $10 \%$ of the total agricultural land (Figure 5).

The establishment of fast-growing tree plantations in the study area would be possible on soils classified in the qualitative groups 5-7 (mediumquality soils). The total area of these soils potentially suitable for wood biomass production is 1,536 ha (Figure 6).

According to Tóth, Stričík and Kuffa (2015), SRC willow plantations can provide dry above-ground biomass yields ranging from 12 to $15 \mathrm{t} / \mathrm{ha}$ in our conditions. Taking into consideration the lower value (12 t/ha), the SRC willows could provide $18,432 \mathrm{t}$ of dry above-ground biomass in the study area. Several studies showed that except of SRC willow, also poplar and miscanthus might be promising crops used for energy purposes in the conditions of south-western Slovakia (Kotrla and Prčík, 2013; Kotrla, Mandrlová and Prčík, 2017a; Kotrla, Mandrlová and Prčík, 2017b; Prčík and Kotrla, 2015).

MacKay (2009) assumes that the best performance of any energy crops in Europe is $0.5 \mathrm{~W} / \mathrm{m}^{2}$. If the whole area of 1,536 ha were covered with SRC plantations it would represent $399 \mathrm{~m}^{2}$ per person. The plantations would produce $200 \mathrm{~W}$ per person and that is $4.8 \mathrm{kWh}$ /day per person. Taking into consideration the overall losses of $33 \%$

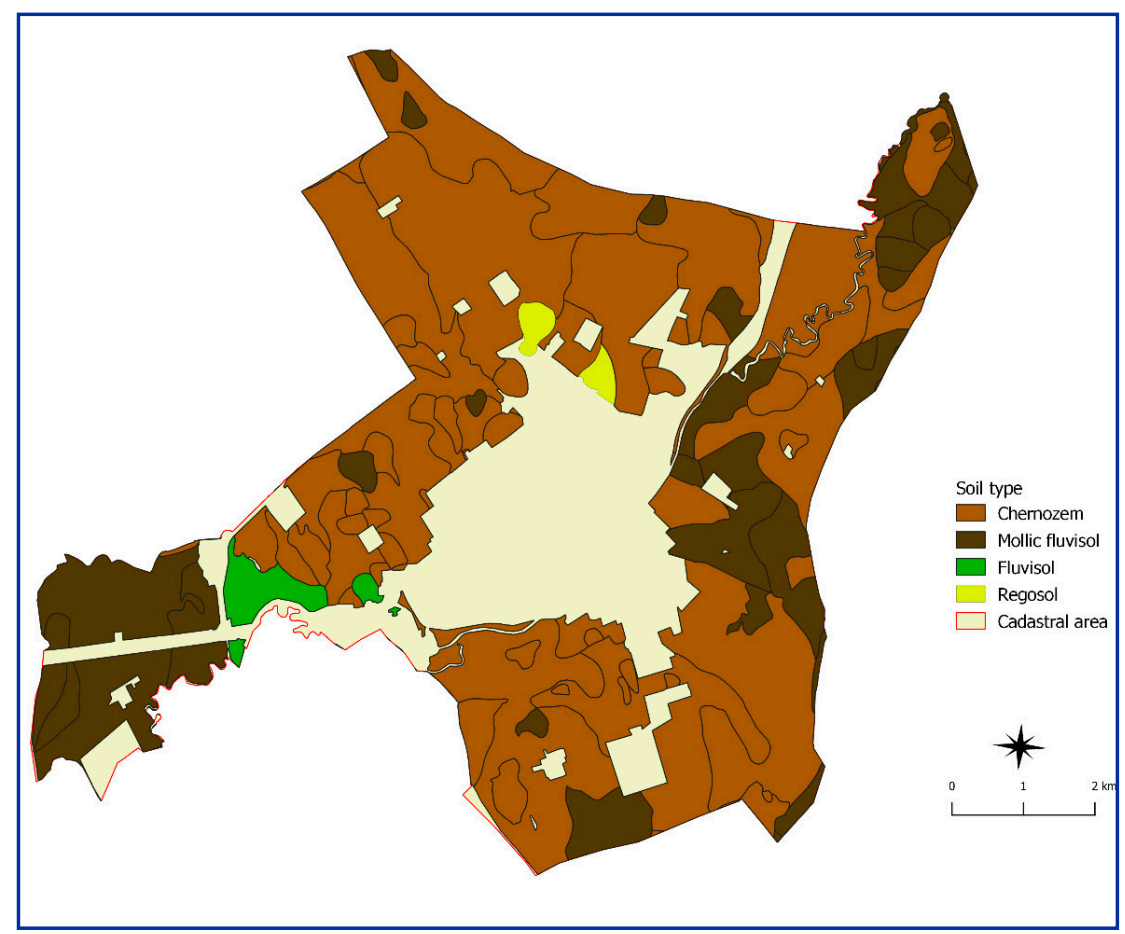

Figure 3 Soil types in the cadastral area of Nové Zámky Source: author

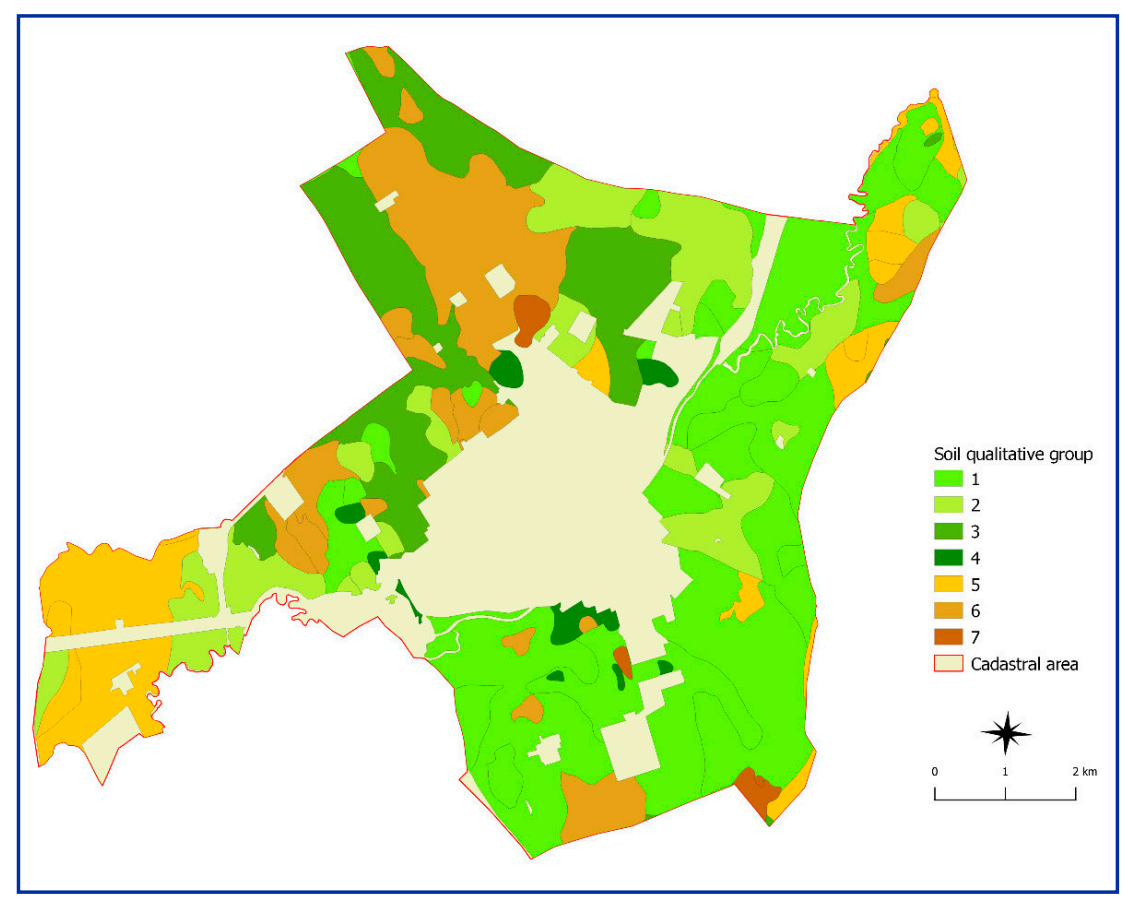

Figure 4 The qualitative classification of the soils Source: author 


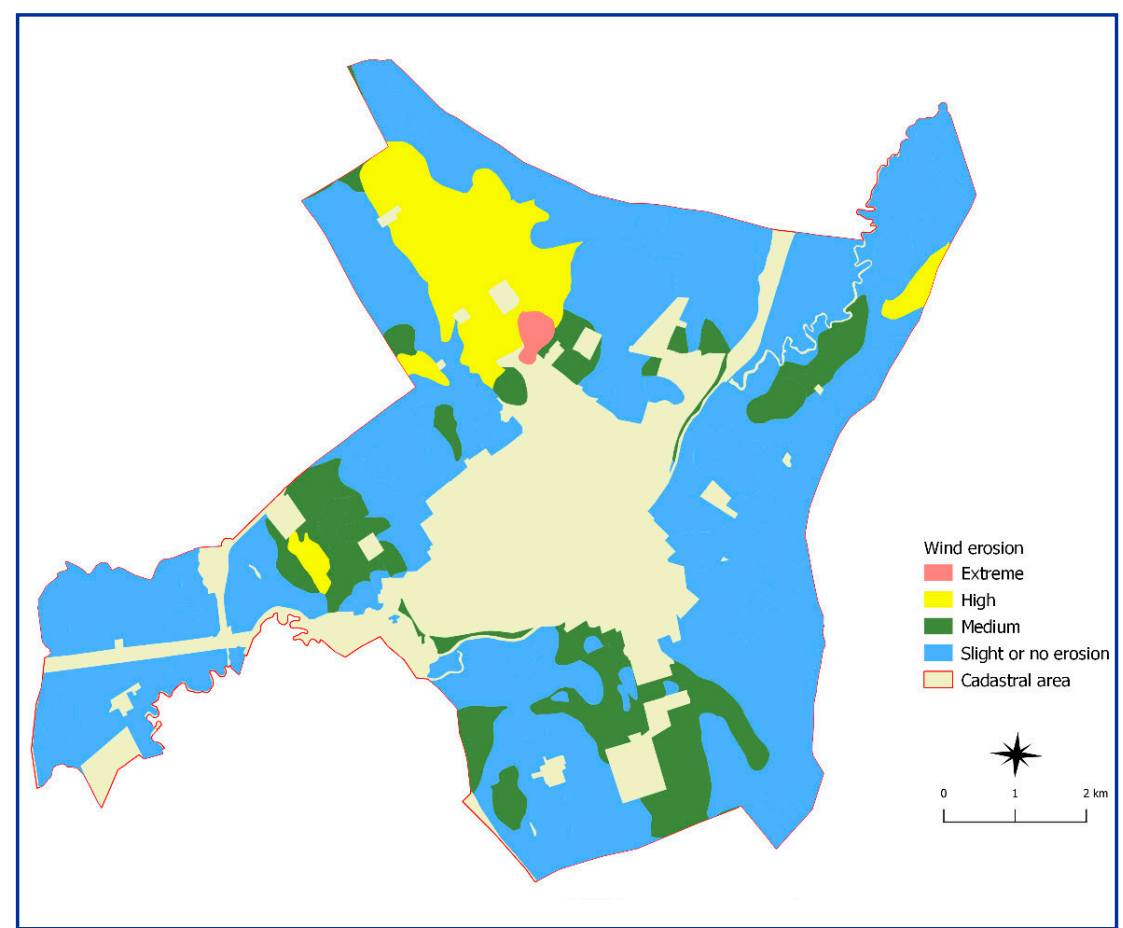

Figure 5 Wind erosion status of the study area Source: author

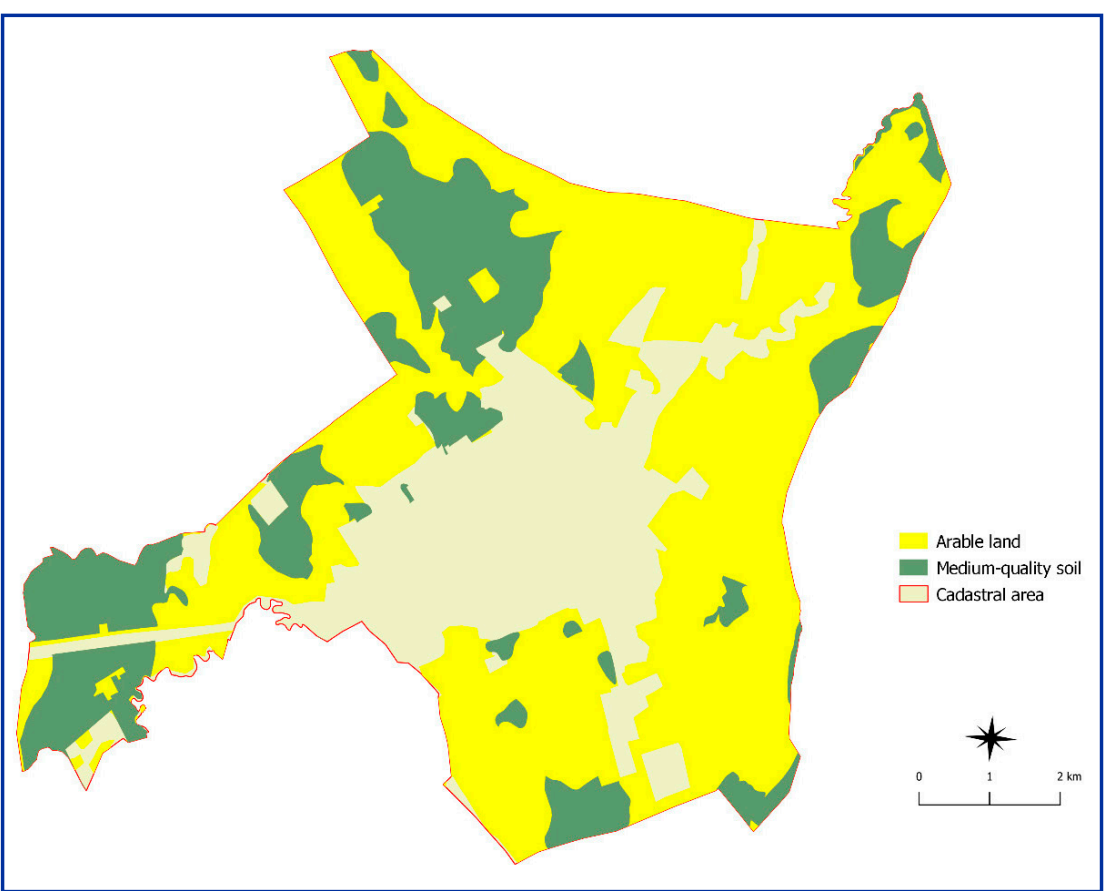

Figure 6 Medium-quality soils potentially suitable for alternative use Source: author in the process of energy conversion, the potential power is $3.2 \mathrm{kWh} /$ day per person.

The calculation of the number of jobs created in biomass production on a short rotation coppice (SRC) plantation was based on Varga and Bartko (2010). The assumption is that 4,000 jobs would be created per 100,000 hectares, i.e. 0.04 jobs per ha. Therefore, if the SRC plantations were established in the area of 1,536 ha, 61 new jobs could be created.

\section{Acknowledgments}

The paper was supported by VEGA grant no. 1/0147/17 and the Grant Agency FESRD no. 2/2017.

\section{References}

AUREX s.r.o. 2016. Land-use plan of Nové Zámky [in Slovak]. [online]. [Retrieved 2018-02-15]. Retrieved from: http:// www.novezamky.sk/assets/File.ashx?id org=700036\&id_dokumenty $=20038$

BILGILI, F. - KOÇAK, E. - BULUT, Ü. - KUŞKAYA, S. 2017. Can biomass energy be an efficient policy tool for sustainable development? In Renewable and Sustainable Energy Reviews, vol. 71, 2017, pp. 830-845. ISSN 18790690.

CONNOLLY, D. - LUND, H. - MATHIESEN, B. V. 2016. Smart Energy Europe: The technical and economic impact of one potential $100 \%$ renewable energy scenario for the European Union. In Renewable and Sustainable Energy Reviews, vol. 60, 2016, pp. 1634-1653. ISSN 18790690.

DA COSTA, T. P. - QUINTEIRO, P. - TARELHO, L. A. C. - ARROJA, L. - DIAP. A. C. 2018. Environmental impacts of forest biomassto-energy conversion technologies: Grate furnace vs. fluidised bed furnace. In Journal of Cleaner Production, vol. 171, 2018, pp. 153-162. ISSN 09596526.

DINCER, I. - ACAR, C. 2017. Smart energy systems for a sustainable future. In Applied Energy, vol. 194, 2017, pp. 225-235. ISSN 03062619.

EEA. 2012. Corine Land Cover 2012 Raster Data. [online]. [Retrieved 2017-11-19]. Retrieved from: https://www.eea.europa. eu/data-and-maps/data/clc-2012-raster

GASPARATOS. A. - DOLL, C. N.H. - ESTEBAN, M. - AHMED, A. - OLANG, T. A. 2017. Renewable energy and biodiversity: Implications for transitioning to a Green Economy. In Renewable and Sustainable Energy Reviews. vol. 70, 2017, pp. 161-184. ISSN 18790690.

GEODETIC AND CARTOGRAPHIC INSTITUTE BRATISLAVA. 2018. Territorial 
administrative units of Slovakia. [online]. [Retrieved 2017-1119]. Retrieved from: https://www.geoportal.sk/sk/zbgis_smd/ na-stiahnutie/

GEOFABRIK GMBH KARLSRUHE. 2017. OpenStreetMap data for Slovakia. [online]. [Retrieved 2018-02-15]. Retrieved from: http:// download.geofabrik.de/europe/slovakia.html

KHANAM, T. - RAHMAN, A. - MOLA-YUDEGO, B. - PELKONEN, P. - PEREZ, Y. - PYKÄLÄINEN, J. 2017. Achievable or unbelievable? Expert perceptions of the European Union targets for emissions renewables and efficiency. In Energy Research and Social Science, vol. 34, 2017, pp. 144-153. ISSN 22146296.

KOTRLA, M. - PRČÍK, M. 2013. Environmental and socio-economic aspect of growing Miscanthus genotypes. In Scientific Papers Series Management, Economic Engineering in Agriculture and Rural Development, vol. 13, 2013, no. 1, pp. 201-204. ISSN 2247-3527.

KOTRLA, M. - MANDALOVÁ, K. - PRČíK, M. 2017a. Regional disparities in Slovakia and the Czech Republic in the context of sustainable growing of energy plants. In European Journal of Sustainable Development, vol. 6, 2017, no. 2, pp. 165-180. ISSN 2239-5938.

KOTRLA, M. - MANDALOVÁ, K. - PRČíK, M. 2017b. Assessing the production potential of purpose-grown energy crops in Slovak regions. In International Multidisciplinary Scientific GeoConference Surveying Geology and Mining Ecology Management, SGEM. SGEM. Sofia: STEP92 Technology, p 75-82. [online]. [Retrieved 201803-18]. Retrieved from: https://www.scopus.com/record/display. uri?eid=2-s2.0-85032454173\&origin=resultslist\&sort=plf-f\&src=s\& st $1=$ Kotrla\%2c+M.\&st2=\&sid $=0$ b41 ea80be5d09

LAPIN, M. - FAŠKO, P. - MELO, M. - ŠŤASTNÝ, P. - TOMLAIN, J. 2002. Climate Regions. In MŽP SR. 2002. Landscape atlas of the Slovak Republic. Banská Štiavnica : Espirit s. r. o, 2002, 94 pp. [in Slovak].

MAcKAY, D. J. C. 2009. Sustainable energy - without the hot air. Cambridge, England : UIT, 2009, ISBN 9780954452933.

MARSINA, K. - LEXA, J. 2002. Basic geochemical types of rocks. In MŽP SR. 2002. Landscape Atlas of the Slovak Republic. Banská Štiavnica : Espirit s. r. o, 2002, 94 pp. [in Slovak].

MOLA-YUDEGO, B. - AREVALO, J. - DÍAZ-YÁÑEZ, O. - DIMITRIOU, I. HAAPALA, A. - FERRAZ FILHO, A. C. - SELKIMÄKI, M. - VALBUENA,
R. 2017. Wood biomass potentials for energy in northern Europe: Forest or plantations? In Biomass and Energy, vol. 106, 2017, pp. 95-103.

NARAYANm R. Rationale, drivers standards and technology for biobased materials. In Graziani, M - Fornasiero, P. (editors). Renewable Resources and Renewable Energy: A Global Challenge. Florida: CRC Press-Taylor and Francis Group Boca Raton, 2007, pp. 3-18.

PRČÍK, M. - KOTRLA, M. 2015. Targeted cultivation of the energy plants in conditions of the Slovak regions. In Scientific Papers Series Management, Economic Engineering in Agriculture and Rural Development, vol. 15, 2015, no. 1, pp. 399-404. ISSN 2284-7995.

STREĎANSKÁ, A. - BUDAJ, Š. 2006. Soil bonitation and price. Nitra : SPU, 2006, pp. 160. ISBN 80-8069-656-X [in Slovak].

THE SLOVAK REPUBLIC. Act No. 220/2004 on the Protection and use of agricultural land, as amended.

TÓTH, Š. - STRIČÍK M. - KUFFA M. 2015. The economics of fastgrowing willow cultivation in conditions of north-eastern Slovakia case study [in Slovak]. [online]. [Retrieved 2018-02-15]. Retrieved from: http://www.agroporadenstvo.sk/ekonomika-financie-trhodborne clanky?article $=605$

VARGA, L. - BARTKO, M. 2010. Production potential of fast-growing trees in Slovakia. In Fast-growing trees - one of the renewable sources of wood and energy. Zvolen : Národné lesnícke centrum, 2010, pp. 53-56. ISBN 978-80-8093-117-9. [in Slovak].

VIDADILI, N. - SULEYMANOV, E. - BULUT, C. - MAHMUDLU, C. 2017. Transition to renewable energy and sustainable energy development in Azerbaijan. In Renewable and Sustainable Energy Reviews, vol. 80, 2017, pp. 1153-1161. ISSN 18790690.

WELFLE, A. 2017. Balancing growing global bioenergy resource demands - Brazil's biomass potential and the availability of resource for trade. In Biomass and Bioenergy, vol. 105, 2017, pp. 83-95. ISSN 18732909. 